Fikrah: Jurnal Ilmu Aqidah dan Studi Keagamaan

issn 2354-6174 eissn 2476-9649

Tersedia online di: journal.iainkudus.ac.id/index.php/fikrah

Volume 9 Nomor 1 2021, (105-132)

DOI: 10.21043/fikrah.v8i1. 10113

\title{
Konservasi Temuan Makam Kuno Keramat dan Perkembangan Islam di Medan
}

\author{
Solihah Titin Sumanti \\ Universitas Islam Negeri Sumatera Utara \\ solihahtitinsumanti@uinsu.ac.id
}

\begin{abstract}
the purpose of this research is to find out how the distribution of the existence of ancient tombs in the city of Medan, the form of management of ancient tombs in the city of Medan based on the Law of Cultural Heritage No. 11 of 2010, and the contribution of the findings of ancient tombs to the development of Islam in the Village Martubung Medan. The method used is transect walk. This method is carried out as a strategy to map the existence of cultural heritage from the existence of complexes of ancient tombs. His findings that the identification of ancient tombs in the city of Medan, especially in Martubung village, namely the Tomb of Datuk Hasan, Tomb of Datuk Payung, Tomb of Datuk Tongah, Datuk Dadih and Tomb of Datuk Hitam. To maintain the cultural heritage, the government collaborates with local communities to conduct socialization and conservation activities that include physical protection, transfer, excavation and recording, maintenance. The discovery of five ancient Islamic tomb complexes in Martubung Village shows the historical events of the entry and development of Islam in North Sumatra and cultural changes through the process of human adaptation to the environment.
\end{abstract}

Keywords: Ancient tombs, cultural heritage, Islam, preservation 


\begin{abstract}
Abstrak
tujuan penelitian ini untuk mengetahui bagaimana sebaran keberadaan makammakam kuno di Kota Medan, bentuk pengelolaan makam-makam kuno di Kota Medan berdasarkan UU Cagar Budaya No. 11 Tahun 2010, dan konstribusi temuan makam kuno terhadap perkembangan Islam di Kelurahan Martubung Kota Medan. Metode yang digunakan adalah transect walk. Metode ini dilakukan sebagai suatu strategi untuk memetakan keberadaan warisan budaya dari adanya kompleks makam-makam kuno. Temuannya bahwa teridentifikasinya makammakam kuno yang ada di Kota Medan khususnya di Desa Martubung yaitu Makam Datuk Hasan, Makam Datuk Payung, Makam Datuk Tongah, Datuk Dadih dan Makam Datuk Hitam. Untuk menjaga cagar budaya tersebut, pemerintah bekerjasama dengan masyarakat setempat melakukan kegiatan sosialisasi dan konservasi yang meliputi perlindungan fisik, pemindahan, ekskavasi dan perekaman, pemeliharaan. Dengan ditemukannya kelima kompleks makam kuno bercorak Islam di Desa Martubung, menunjukkan adanya peristiwa sejarah masuk dan berkembangnya Islam di Sumatera Utara dan perubahan budaya melalui proses adaptasi manusia terhadap lingkungan.
\end{abstract}

Kata kunci: Cagar budaya, Islam, makam kuno, pelestarian

\title{
Pendahuluan
}

Makam adalah wujud budaya Islam yang mencerminkan persepsi dan alam pikir masyarakatnya. Makam tidak hanya sekadar benda yang mewakili makna fungsional sebagai benda kubur. Makam sangat sakral akan simbol, nilai kebudayaan yang sangat tinggi, mewakili persepsi komunitasnya tentang alam pikir kematian, kehidupan, dan kehidupan setelah kematian, serta makam dapat menjadi satu bukti masuk dan berkembangnya Islam di suatu tempat (Yatim, 1988). Misalnya di Barus, makam tertua yang ditemukan pada kompleks makam Ibrahimsyah dengan batu nisan bertarikh $1356 \mathrm{H}$ menjadi data bendawi penting mengenai kapan masuknya Islam di pantai barat Sumatera Utara (Perret, 2007; Perret \& Surachman, 2015; Suprayitno, 2011, 2012). Di Barus juga terdapat sebuah makam yang memiliki nilai kesakralan yang sangat tinggi yakni makam Syekh Mahmud yang ada di kompleks makam Papan Tinggi. Meski makam ini terletak di atas bukit yang sangat tinggi dan hanya dapat dicapai dengan menaiki tanggal setapak sejumlah 800 anak tangga, namun makam ini selalu rutin diziarahi oleh masyarakat. Biasanya masyarakat Islam datang berziarah ke Papan Tinggi untuk memanjatkan doa atau bernazar (Suprayitno, 2012).

Makam-makam kuno yang ada di Kota Medan menjadi salah satu data sejarah penting untuk menentukan tanggal lahirnya Kota Medan. Berdasarkan Laporan Panitia Peneliti Hari Jadi Kota Medan menyebutkan bahwa titik tolak berdirinya Kota Medan didasarkan pada temuan sebuah makam di Klumpang 
atas nama Imam Saddik bin Abdullah dengan batu nisan bertarikh 23 Sya'ban $998 \mathrm{H}$ atau 27 Juni 1590 (Azhari, 2011). Tokoh Imam Saddik dianggap merupakan makam seorang ulama asal Jawa yang berhasil mengislamkan tokoh legendaris asal Sumatera Utara yakni Guru Patimpus. Makam tersebut saat ini telah menjadi salah satu makam keramat di Kota Medan yang kadang kala dikunjungi oleh peziarah (Hartini, 2011a; Suprayitno, 2001). Oleh sebab itu makam menjadi salah satu data arkeologi penting berkaitan dengan sejarah Islam yang harus dikaji dengan lebih serius dan dikelola pelestarian bahkan pemanfaatannya.

Keberadaan makam kuno di Kota Medan saat ini sering kali terabaikan baik dari aspek penelitian maupun pengelolaan. Sebagai besar makam kuno yang ada di Kota Medan kondisinya kurang terawat dan rawan rusak. Akan tetapi, hingga pendataan objek yang diduga cagar budaya Kota Medan pada tahun 2018 oleh Dinas Kebudayaan Kota Medan, keberadaan makam kuno sebagai bagian dari struktur cagar budaya sama sekali tidak termuat (Hartini, 2011b). Keberadaan makam kuno memiliki nilai penting sejarah, budaya, agama, dan ilmu pengetahuan yang sangat tinggi. Beberapa makam-makam kuno di Kota Medan justru disalahgunakan pemanfaatannya, misalnya menjadi objek ritual oleh etnis Tionghoa yang beragama Buddha atau objek pemujaan (Sumanti \& Batubara, 2019). Hal tersebut diakibatkan karena anggapan tingginya nilai kesakralan dan magis yang ada pada makam kuno tersebut, sementara keberadaan makam tidak mendapat pendampingan dari pihak yang memahami untuk melestarikannya.

Objek makam-makam kuno dapat termasuk dalam objek kajian strategis bagi mahasiswa Prodi Sejarah Peradaban Islam (SPI) UINSU. Hingga saat ini baru terdata hanya tiga kompleks makam kuno yang ada di Kota Medan yakni makam di Jalan Karo, makam di Jalan Putri Hijau, dan makam di Jalan Palang Merah. Sedangkan potensi heritage bercorak Islam di Kota Medan masih begitu besar. Dalam beberapa sumber lisan yang berkembang di masyarakat sering kali dilaporkan temuan makam-makam kuno atau yang lebih dikenal dengan sebutan makam keramat. Namun penelitian mengenai makam-makam tersebut sama sekali belum dilakukan. Temuan-temuan baru terhadap tinggalan makam kuno dapat menjadi data untuk menggugat dan merekonstruksi ulang sejarah masuk dan berkembangnya Islam di Kota Medan yang selama ini telah diketahui. Selain itu, objek penelitian makam-makam kuno dapat dijadikan sebagai bahan yang memperkaya khasanah jejak sejarah peradaban Islam di Kota Medan. Melalui penelitian pada makam-makam kuno 
ini, mahasiswa Prodi SPI dapat melakukan langsung penelitian lapangan dengan menerapkan berbagai metode penelitian baik dari perspektif sejarah, arkeologi, maupun budaya.

Mahasiswa Prodi Sejarah Peradaban Islam dapat turut serta menyusun pengelolaan makam kuno di Kota Medan sebagai bentuk pengabdiannya kepada masyarakat yang bertujuan membangun kesadaran sejarah dalam masyarakat luas. Pemanfaatan makam kuno yang sejauh ini telah dilakukan dianggap menyimpang dari perspektif sejarah maupun tauhid karena tidak didampingi oleh pihak yang berkompetensi. Setidaknya pengetahuan yang dimiliki oleh Prodi SPI UINSU yang tidak hanya dari aspek sejarah namun juga dari aspek agama, budaya dan pendidikan dapat menjadikan upaya pengelolaan makam kuno menjadi lebih terarah, sistematis, benar dan lebih terasa kebermanfaatannya bagi masyarakat.

Hasil penelitian terhadap kompleks makam kuno yang telah teridentifikasi di Sumatera Utara menunjukkan bahwa masuk dan berkembangnya Islam di Sumatera Utara melalui beberapa fase mulai dari abad ke-14 - ke-18 M. Namun uniknya untuk kawasan pantai barat Sumatera Utara, dari rentang abad ke-14 M hingga ke-18 $\mathrm{M}$, perkembangan Islam terus berlanjut meski berpindah-pindah, sedangkan untuk kawasan pantai timur tidaklah sama. Dari penelitian tipologi batu nisan yang tersebar di pantai timur Sumatera Utara menunjukkan perkembangan Islam baru di mulai abad ke-15 M - ke-16 M. Permasalahan yang dibahas dalam artikel ini adalah: (1) bagaimana sebaran keberadaan makam-makam kuno di Kota Medan?; (2) bagaimana masyarakat dan mahasiswa melakukan aktivitas pada makammakam kuno di Kota Medan?; dan (3) bagaimana bentuk pengelolaan makammakam kuno di Kota Medan berdasarkan UU Cagar Budaya No. 11 Tahun 2010?; (4) bagaimana konstribusi temuan makam kuno terhadap perkembangan Islam di Kelurahan Martubung Kota Medan?

\section{Kajian Teori}

\section{Makam Kuno dalam Perspektif Arkeolog}

Istilah makam berasal dari bahasa Arab, qama, dalam bentuk tunggal maskulin menjadi maqamun berarti tempat atau posisi berdiri. Istilah makam disamakan artinya dengan kubur. Istilah kubur dalam bahasa Arab berasal dari kata qabara yang berarti mengebumikan jenazah. Di beberapa tempat di Indonesia ada yang disebut astana (Jawa, Sunda, Banjar, Cirebon, Banten), 
setana (Jawa), asta (Madura), astano dan ustano (Minang). Dalam hal ini kubur dianggap sebagai istana bagi yang mati (Wibisono et al., 1989). Kesan kemewahan itu dikaitkan dengan si mati yang tinggal di surga dan dikasihi Tuhan. Di Aceh istilah kandang sering digunakan untuk makam para Sultan (Lombard, 2008).

Batu nisan, jirat dan cungkup merupakan tanda makam. Batu nisan terutama di daerah Sumatera Barat dan Banjar disebut dengan istilah mejan. Asal kata nisan telah menimbulkan berbagai tafsiran. L. Ch. Damais mencatat beberapa pendapat para ahli terhadap asal muasal kata nisan ditinjau dari berbagai bahasa dan akar katanya. Salah satu yang dikemukakan adalah pendapat Van der Tuuk yang mengarahkan bahwa bahasa asalnya dari Persia. Arti nisan adalah tanda yang dalam bahasa Arab berarti Syahid (saksi).

Di Jawa kata tetengger berarti tanda sering disamakan dengan arti maesan. Hidding berpendapat, tak tertutup kemungkinan kata pasean berasal dari kata maesan bahkan dari kata maejan, sedangkan Th. Piqeaud menyatakan bentuk asli adalah kata maejan dan kata maesan merupakan bentuk sekunder. Kamus Greeke \& Roorda mencatat, maesan berarti kebowan (menyerupai kerbau), sehingga L. Ch. Damais berkesimpulan nisan atau maesan berasal dari bahasa Sansekerta, mahisa (kerbau), disokong oleh pernyataan bahwa masa pra-Hindu terdapat tradisi menegakkan batu dan menyembelih kerbau pada upacara persembahan (Duli et al., 2013). Barangkali kesimpulan yang disebut Damais mendekati benar karena pada zaman Hindu bahkan sampai sekarang di beberapa tempat di Indonesia masih ada masyarakat yang melakukan ritual keagamaan yang cenderung megalitis menempatkan kerbau sebagai binatang korban serta disertai dengan pendirian bangunan dari batu (Ambary \& Ali, 1988, hal. 10).

Nisan di dalam Islam berfungsi tidak lebih sebagai penanda kubur (Wibisono et al., 1989), untuk membedakan bagian kepala dan kaki serta arah bujur si mayat yang dikuburkan. Oleh karena orientasi arah hadap nisan di Indonesia selalu ke utara-selatan. Jirat biasa juga disebut kijing adalah bangunan persegi panjang dibuat di atas permukaan tanah bekas lubang kubur (Perret, 2007; Suprayitno, 2012).

Di Aceh bangunan jirat sering mempergunakan lempengan batu yang telah ditatah dan dihias sedemikian rupa, bahkan ada yang berupa semen yang dibentuk seindah mungkin, tergantung kepada status sosial dan kondisi ekonomi orang yang dikuburkan. Oleh sebab itu, seringkali makam kuna yang 
merupakan makam orang kaya, bangsawan, tokoh masyarakat dan ulama tampil dengan indah dan mewah sekali, sedangkan jirat masyarakat biasa hanya dilengkapi dengan jirat berupa tumpukan tanah atau dengan susunan batu saja (Oetomo, 2016; Perret, 2007; Suprayitno, 2012).

Selain nisan dan jirat, kadang kala sebuah makam dilengkapi dengan cungkup yaitu bangunan beratap sebagai penutup dan pelindung makam (Ambary \& Ali, 1988). Sama halnya dngan jirat, cungkup ada juga yang dibuat sangat sederhana tetapi tak jarang muncul sangat indah dan raya hiasan, tergantung dengan status sosial dan kondisi ekonomi orang yang dimakamkan.

\section{Pelestarian dan Konservasi}

Sumber daya arkeologi merupakan salah satu kekayaan peninggalan sejarah dan purbakala masa lalu. Keberadaan sumberdaya arkeologi ini merupakan kekayaan khasanah budaya di Indonesia, juga sebagai cermin kepribadian bangsa dan melahirkan, sifat nasionalisme, dan kemajemukan budaya ini pula akan mempererat persatuan dan kesatuan bangsa. Oleh sebab itu sumberdaya arkeologi perlu dilestarikan dengan sebaik-baiknya, dijaga, dibina, dan dikembangkan potensinya sebagai aset nasional.

Upaya pelestarian dilakukan dengan tetap memperhatikan bentuk keasliannya, sehingga perlu diadakan studi konservasi. Untuk lebih memahami tentang konservasi sebagai salah satu kajian studi arkeologi, maka penulis menguraikan sebagai berikut tentang konservasi: 1) Konservasi mempunyai pengertian yang bermacam-macam tergantung dalam pemakaian istilah tersebut; 2) Dalam Kamus Besar Bahasa Indonesia konservasi adalah pemeliharaan dan perlindungan sesuatu secara teratur untuk mencegah kerusakan dan kemusnahan dengan jalan mengawetkan.

Konservasi ini memiliki peranan yang sangat penting dalam upaya perbaikan, pemeliharaan, penyusunan kembali komponen suatu bangunan pada bentuk aslinya tanpa mengabaikan nilai sejarah, arkeologis, arsitektur dan sebagainya. Menurut Sadirin konservasi adalah tindakan yang bersifat kuratif (pengobatan) terhadap Benda Cagar Budaya yang terkena penyakit dan tidak bisa ditangani dengan metode perawatan sederhana (Joentono, 1996; Sadirin, 1999, hal. 23).

Adapun langkah-langkah dalam upaya pelestarian sumberdaya arkeologi antara lain: 1) Pendokumentasian, yaitu suatu kegiatan perekaman (recording) yang dapat menyajikan informasi atau membuktikan tentang 
sesuatu hal, dokumentasi juga merupakan wahana wadah pengetahuan dan ingatan manusia; 2) Kegiatan pelestarian, kegitan ini meliputi pelaksanaan perawatan (conservation) untuk sumberdaya arkeologi yang telah mengalami proses pelapukan, serta bila perlu dilakukan pemugaran atau restoration bagi objek-objek yang mengalami kerusakan serius. Serta penataan lingkungan atau lanscape guna lebih menjaga pelestarian dan kelestarian sumberdaya arkeologi (Kasnowihardjo, 2001, hal. 21).

\section{Konservasi Cagar Budaya}

Istilah konservasi merupakan isilah yang sangat umum digunakan dalam berbagai bidang, mulai dari kehutanan, lingkungan, energi, hingga bidang lain seperti kedokteran. Namun, apa yang dimaksud dengan konservasi dalam bidang pelestarian cagar budaya. Demikian luasnya pengertian konservasi sehingga seringkali justru menimbulkan kesalahpahaman dan kerancuan. Saat ini kita mengenal istilah konservasi dalam arti luas dan konservasi dalam arti sempit. Konservasi yang dibahas dalam hal ini adalah berkaitan dengan pelestarian warisan budaya, yang penekanannya pada budaya tidak bergerak yaitu struktur atau monument yang merupakan sumberdaya arkeologi yang perlu diletarikan dari kepunahan dan kehancurannya. Sumberdaya arkeologi merupakan salah satu kekayaan peninggalan sejarah dan purbakala masa lalu (Kasnowihardjo, 2001).

Keberadaan sumberdaya arkeologi ini merupakan kekayaan khasanah budaya di Indonesia, juga sebagai cermin kepribadian bangsa dan melahirkan, sifat nasionalisme, dan kemajemukan budaya ini pula akan mempererat persatuan dan kesatuan bangsa. Oleh sebab itu sumberdaya arkeologi perlu dilestarikan dengan sebaik-baiknya, dijaga, dibina, dan dikembangkan potensinya sebagai aset nasional. Upaya pelestarian dilakukan dengan tetap memperhatikan bentuk keasliannya, sehingga perlu diadakan studi konservasi. Dalam bidang Benda Cagar budaya Agrawal \& Barkeshli membatasi pengertian konservasi yaitu, "any action taken to determine the nature or properties of materials used in any kinds of cultural holdings or in their housing, holding or treatment, any action taken to understand and control the causes of deterioration and any action taken to better the condition of such holding" (Agrawal \& Barkeshli, 1997, hal. 5).

Konservasi dalam pengertian yang sederhana adalah kegiatan perawatan dengan cara pengawetan terhadap Benda Cagar Budaya yang telah mengalami pelapukan dan kerusakan baik secara mekanis, fisis, kimia, 
maupun biologis. Konservasi ini memiliki peranan yang sangat penting dalam upaya perbaikan, pemeliharaan, penyusunan kembali komponen suatu bangunan pada bentuk aslinya tanpa mengabaikan nilai sejarah, arkeologis, arsitektur dan sebagainya (McKercher \& Cros, 2002; Munjeri, 2007; Pearson \& Sullivan, 2010). Menurut Sadirin konservasi adalah tindakan yang bersifat kuratif (pengobatan) terhadap Benda Cagar Budaya yang terkena penyakit dan tidak bisa ditangani dengan metode perawatan sederhana (Sadirin, 1999). Dengan demikian konservasi dapat diartikan dalam lingkup pengertian yang cukup luas, dan dalam hal ini konservasi didefinisikan sebagai berikut: 1) Setiap upaya yang dilakukan untuk mengetahui sifat-sifat bahan yang dipakai untuk membuat Benda Cagar Budaya; 2) Setiap upaya untuk mengetahui penyebab perusakan dan pengendalian atau pencegahan terhadap kerusakan benda yang lain; 3) Setiap perbuatan untuk memperbaiki keadaan atau kondisi Benda Cagar Budaya (Joentono, 1996). Selain itu konservasi juga dapat diartikan sebagai segala macam upaya untuk melestarikan cagar budaya termasuk perlindungan, pemanfaatan, dan pengembangan (McKercher \& Cros, 2002; Pearson \& Sullivan, 2010).

Konservasi dalam arti luas memiliki cakupan yang sangat luas, atau bisa diartikan sebagai preservasi atau pelestarian itu sendiri. Sedangkan konservasi dalam arti sempit adalah usaha-usaha untuk mempertahankan kelestarian material benda cagar budaya termasuk nilai-nilai yang terkandung, yang mencakup tindakan pemeliharaan, treatment, dan pengawetan. Konservasi dalam arti sempit lebih cenderung pada kegiatan teknis yang melibatkan material BCB dan bahan-bahan kimia konservasinya. Merujuk pada UndangUndang Cagar Budaya Nomor 11 Tahun 2010, istilah konservasi secara eksplisit sudah tidak lagi ada. Hal ini untuk menghindari adanya kesalah pahaman dan kerancuan. Istilah baru yang digunakan untuk menggantikan konservasi dalam arti luas adalah Pelindungan.

Kata pelindungan setara dengan istilah "protection" dalam bahasa Internasional yang sering dipergunakan. Pengertian yang termaktub dalam Undang-Undang tersebut adalah sebagai berikut: "Pelindungan adalah upaya untuk mencegah dan menanggulangi segala kerusakan, kehancuran, atau kemusnahan Cagar Budaya yang disebabkan oleh perbuatan manusia atau proses alam, baik secara fisik maupun hukum melalui upaya penyelamatan, pengamanan, pemeliharaan, pemugaran, zonasi, pendaftaran, penetapan, dan pemberian surat keterangan pemilikan." (Undang-Undang No. 11 Tahun 2010 tentang Benda Cagar Budaya, 2010). Dengan demikian maka ke depan istilah 
konservasi lebih cocok untuk diartikan sebagai konservasi dalam arti sempit, yaitu berkonotasi pada tindakan perbaikan, treatment, pemeliharaan, pengawetan dan usaha-usaha teknis lainnya (Pearson \& Sullivan, 2010).

Undang-undang juga telah menjelaskan istilah pemeliharaan yang mengandung pengertian sebagai berikut, "Pemeliharaan adalah upaya mempertahankan kondisi fisik Cagar Budaya dari kerusakan, kehancuran, atau kemusnahan yang diakibatkan, baik oleh manusia maupun alam, melalui perawatan dan pengawetan." Selain itu tercantum istilah pemugaran yang mengandung pengertian "Pemugaran adalah upaya mengembalikan kondisi fisik Benda Cagar Budaya, Bangunan Cagar Budaya, dan Struktur Cagar Budaya yang rusak sesuai dengan keaslian bahan, bentuk, tata letak, dan/atau teknik pengerjaan untuk memperpanjang usia".

Aspek lainnya yang cukup penting adalah aspek pengembangan yakni "Pengembangan adalah peningkatan potensi nilai, informasi, dan promosi Cagar Budaya serta pemanfaatannya melalui Penelitian, Revitalisasi, dan Adaptasi secara berkelanjutan serta tidak bertentangan dengan tujuan Pelestarian" (Undang-Undang No. 11 Tahun 2010 tentang Benda Cagar Budaya, 2010). Konservasi merupakan suatu upaya yang dapat menghidupkan kembali vitalitas lama yang telah pudar. Termasuk upaya konservasi bangunan kuno dan bersejarah. Peningkatan nilai-nilai estetis dan historis dari sebuah bangunan bersejarah sangat penting untuk menarik kembali minat masyarakat untuk mengunjungi kawasan atau bangunan tersebut sebagai bukti sejarah dan peradaban dari masa ke masa (Bintarto, 1995).

Upaya konservasi bangunan bersejarah dikatakan sangat penting. Selain untuk menjaga nilai sejarah dari bangunan, dapat pula menjaga bangunan tersebut untuk bisa dipersembahkan kepada generasi mendatang. Telah diketahui bersama bahwa benda manapun yang ada di dunia ini pasti akan mengalami proses degradasi yang mengakibatkan penurunan kualitas bahan dasar yang digunakan, hal ini dikarenakan bahwa sumberdaya arkeologi selalu berinteraksi dengan kondisi lingkungan, yang pada akhirnya akan mempercepat proses kerusakan dan pelapukan yang menyebabkan hancurnya komponen bahan dasar. Pada hakekatnya semua sumberdaya arkeologi akan mengalami interaksi dengan lingkungannya (Joentono, 1996; Kasnowihardjo, 2001). 
Interaksi tersebut merupakan proses alami yang tidak dapat dihindari, sebab pada dasarnya semua benda yang ada di alam ini akan mengalami proses penuaan alamiah dan akan mengalami proses degradasi. Oleh sebab itu kehadiran konservasi menjadi semacam kebutuhan untuk melestarikan sumber daya arkeologi yang diketahui mengalami degradasi mutu secara tajam.

\section{Metode}

Penelitian ini menggunakan metode kualitatif dengan penalaran induktif yang berpegang pada data yang ditemukan di lapangan kemudian dikonstruksi menjadi hipotesis (Pariwisata, 2008; Prangnell et al., 2010; Suryana, 2010, hal. 39). Penelitian ini bersifat eksplikatif yaitu memberikan gambaran data arkeologi yang ditemukan, baik dalam kerangka waktu, bentuk maupun keruangan serta mengungkapkan hubungan di antara berbagai variabel penelitian. Oleh sebab itu, peneliti diharuskan melakukan pengamatan langsung secara cermat di lapangan serta melakukan wawancara secara intensif kepada para narasumber. Maka tahapan yang dilakukan dalam penelitian ini meliputi identifikasi masalah, pengumpulan data, analisis data, dan pemberian sintesis.

Penelitian ini menggunakan pendekatan Participatory Action Research (PAR) sebab dalam penelitian ini akan menghubungkan proses penelitian ke dalam proses perubahan sosial. Perubahan sosial yang dimaksud adalah bagaimana dalam proses pemberdayaan dapat mewujudkan tiga tolak ukur yakni adanya komitmen bersama dengan masyarakat, adanya local leader dalam masyarakat dan adanya institusi baru dalam masyarakat yang dibangun berdasarkan kebutuhan. Penelitian ini akan memberikan kontribusi bagi masyarakat alam menemukan solusi praktis bagi masalah bersama dan isu-isu yang memerlukan aksi dan refleksi bersama. (Afandi et al., 2016, hal. 55; Chambers, 1996; Salim, 2006).

Maksudnya penelitian tersebut dengan pendekatan dan teori yang digunakan dalam penelitian ini ialah selama penelitian lapangan berlangsung, dilakukan pengumpulan data penelitian yang meliputi observasi, survey dan wawancara dengan juru kunci dan penduduk sekitar. Survey yang dilakukan berupa survey permukaan dengan metode transek walk. Hal ini dilakukan untuk memperoleh data penunjang yang terkait dengan keberadaan peninggalan yang ada di kompleks makam. Metode transek walk yang dipakai dalam 
penelitian ini maksudnya yaitu dengan berjalan dengan informan secara sistematis melewati suatu area, mengamati, menanyakan, mendengarkan, mendiskusikan dan pemecahannya. Metode ini dilakukan sebagai suatu strategi untuk memetakan keberadaan warisan budaya dari adanya kompleks makam-makam kuno tersebut.

\section{Makam Kuno dan Perkembangan Islam Awal}

Penelitian dilaksanakan di Kelurahan Martubung, Kecamatan Medan Labuhan, Medan. Kecamatan Medan Labuhan berbatasan langsung dengan kecamatan Medan Deli di sebelah selatan, kecamatan Medan Belawan di sebelah utara, kecamatan Medan Marelan di sebelah barat, dan kabupaten Deli Serdang di sebelah timur. Kecamatan Medan Labuhan merupakan salah satu kecamatan di Kota Medan yang mempunyai luas sekitar 41,275 km² (Kota Medan dalam Angka 2017, 2017, hal.3). Adapun kondisi bentang lahan di wilayah ini cenderung merupakan bekas rawa yang menyusut airnya, dengan ketinggian sekitar 3-4 mdpl.

Martubung merupakan salah satu kelurahan yang berada di wilayah administrasi Kecamatan Medan Labuhan. Dalam sejarah perkembangan Kota Medan nama Labuhan sering disebut-sebut sebagai lokasi terawal dari Kerajaan Deli yang difungsikan tidak hanya sebagai kawasan istana namun terlebih lagi sebagai kawasan pelabuhan perdagangan. Temuan kompleks makam kuno Martubung ini menjadi data terbaru yang belum ditemukan sebelumnya mengenai hubungan sejarah Labuhan dengan sejarah masuk atau berkembangnya Islam di Sumatera Utara. Secara geografis kompleks makam Martubung berada pada titik koordinat $3^{\circ} 42^{\prime}, 11^{\prime \prime}$ Lintang Utara dan $98^{\circ} 41^{\prime}$, $1,80^{\prime \prime}$ Lintang Timur. Dari pengamatan yang dilakukan ditemukan dua kompleks makam yang masih utuh, yakni: 1) Kompleks Makam Datuk Tongah yang berada di sisi utara Masjid Al-Mukarromah dan 2) Kompleks Makam Datuk Payung yang berada di tengah-tengah perkuburan Tionghoa. Kompleks Makam I berada di Jalan Teluk Haru atau Jalan Cing Huan dan kompleks Makam II berada di Jalan Kuburan Cina, Kelurahan Martubung, Kecamatan Medan Labuhan.

Nisan dari beberapa pemakaman lain, seperti Datuk Hitam, Datuk Dadih, dan Datuk Hasan saat ini sudah rusak/hilang sehingga tidak diketahui latar belakang dari tokoh yang dimakamkan. Namun menilik keterkaitan dari beberapa makam tersebut dalam cerita masyarakat diperkirakan berasal dari periode yang tidak berjauhan. Dengan kata lain datuk-datuk tersebut 
merupakan beberapa tokoh yang berasal dari masa yang tidak jauh berbeda. Tiga makam merupakan makam-makam tokoh dengan nisan memiliki persamaan dengan tokoh-tokoh yang berasal dari Aceh sehingga besar kemungkinan merupakan tokoh yang memiliki hubungan erat dengan Aceh pada masa kejayaan Kesultanan Aceh Darussalam.

Nisan yang terdapat pada makam Datuk Tongah memiliki persamaan dengan makan dari tokoh agama yang cukup berpengaruh di Aceh, yaitu Syekh Abdurrauf as-Singkili, sehingga tokoh yang dimakamkan di kompleks makam Datuk Tongah merupakan tokoh yang cukup berpengaruh dalam hal keagamaan di Kota Medan. Selain itu, ada juga nisan pada Makam II yang umum digunakan pada makam-makam pada masa kejayaan Kesultanan Aceh Darussalam. Tidak diketahui apakah nisan tersebut merupakan nisan dari makam seorang tokoh keagamaan ataupun merupakan nisan dari para pejabat Kesultanan Aceh Darussalam, demikian juga dengan makam 2 di kompleks makam Datuk Tongah. Akan tetapi, tokoh tersebut memiliki pengaruh yang besar terhadap perkembangan Islam di Kota Medan.

Tidak diketahui bagaimana keterkaitan nisan-nisan tersebut dengan sejarah awal Kesultanan Deli sebelum akhirnya istana kerajaannya dipindahkan ke Istana Maimun. Besar kemungkinan keduanya memiliki keterkaitan mengingat keduanya (istana Kesultanan Deli dan kompleks makam datuk-datuk tersebut). Selain itu keduanya berasal dari periode yang tidak terlalu jauh. Seperti diketahui, asal muasal Kesultanan Deli dalam sejarah disebutkan berasal dari Aceh atau setidaknya mendapat pengaruh kuat dari Aceh yang ditandai dengan pengislaman kerajaan Deli yang sebelumnya berasal dari kerajaan Deli yang lebih tua. Dalam sejarah lokal kesultanan Deli disebutkan mendapat pengaruh dari Aceh setelah penaklikan yang dilakukan oleh Gocah Pahlawan (Sinar, 1971, 1991, 2006). Apakah keduanya memiliki keterkaitan? Hal itu perlu dibuktikan dengan penelitian-penelitian lanjutan, misalnya dengan mencari tinggalan artefaktual ataupun monumental yang mampu mempertautkan keduanya. Tinggalan artefaktual ataupun monumental dimaksud misalnya adalah temuan berupa fragmen keramik yang mampu memberikan pertanggalan pada situs ataupun temuan monumental berupa maka-makam yang menjembatani hubungan keduanya.

Kompleks makam kuno Martubung yang menjadi objek kajian arkeologis penelitian ini yakni 5 kompleks makam kuno yang berada pada 5 lokasi yang berbeda. Adapun jarak terdekat antar kompleks makam adalah 200 m dan jarak paling jauh sejauh $1 \mathrm{~km}$. Kelima kompleks makam tersebut adalah 
Makam Datuk Hasan, Makam Datuk Payung, Makam Datuk Tongah, Datuk Dadih dan Makam Datuk Hitam. Keberadaan makam kuno di Martubung ditandai oleh keberadaan batu-batu nisan dengan tipologi tua. Secara umum lokasi makam kuno tersebut telah padat dengan permukiman penduduk.

\section{Temuan Makam dan Upaya Konservasi}

Makam Datuk Tongah berada di Kelurahan Martubung, Kecamatan Medan Labuhan. Luas areal kompleks makam ini kurang lebih memiliki lebar 4,4 $\mathrm{m}^{2}$ dan panjang 5,1 $\mathrm{m}^{2}$. Di kompleks ini terdapat 2 makam utuh dengan 4 batu nisan yang masih kondisi baik. Makam Datuk Tongah yang terletak di sebelah utara Masjid Al-Mukarromah, relatif lebih terawat. Makam tersebut konon sampai saat ini masih dijadikan sebagai tempat ziarah. Kompleks makam ini terletak di tengah permukiman masyarakat yang padat penduduknya. Masjid Al-Mukarromah merupakan masjid baru yang dibangun jauh setelah makam tersebut ada. Pembaruan terhadap makam Datuk Tongah terdapat pada pagar makam, dan pelapisan lantai semen pada makam (Sumanti \& Batubara, 2019).

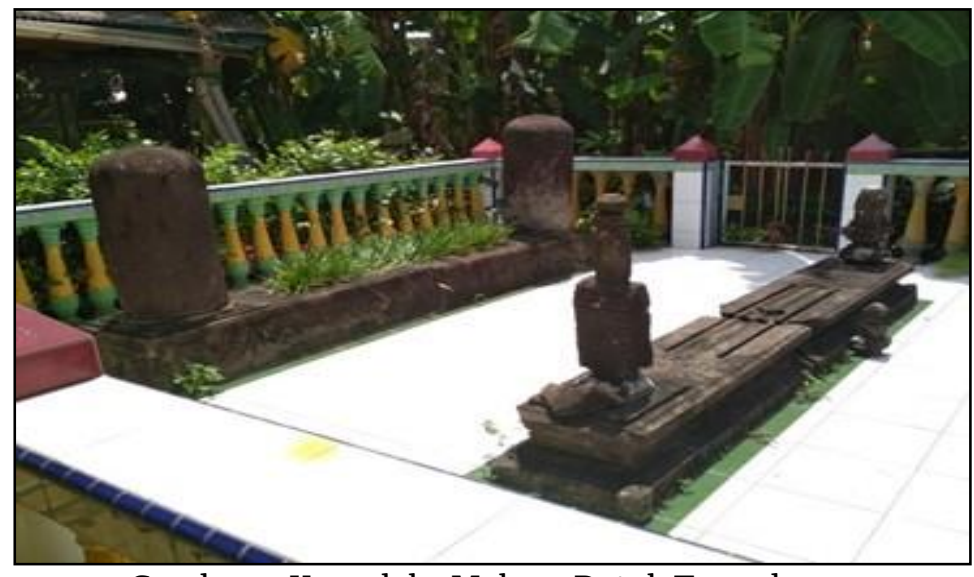

Gambar 1. Kompleks Makam Datuk Tongah

Makam ini memiliki panjang 2,6 $\mathrm{m}$ dan lebar 40,4 cm dengan pembagian bentuk terdiri dari jirat dan batu nisan. Jirat makam masih utuh dengan tinggi $29 \mathrm{~cm}$ dan lebar 30,9 cm - 40,4 cm. Jirat makam terdiri dari dua tingkat, dengan tingkat dasar yang diisi oleh hiasan bunga lotus yang merambat, sedangkan pada tingkat atas diisi hiasan akolade yang disusun menyerupai barisan awan. Bagian permukaan jirat diisi dengan 4 alur menyerupai parit dengan hiasan bunga seuleopu khas Aceh pada bagian tengah, serta hiasan bunga awan dengan teknik stilir perpaduan antara elemen pola anyam tali dan ujung-ujung berbentuk tumbuhan. 
Batu nisan sebelah utara memiliki tinggi $43 \mathrm{~cm}$ yang dapat dibagi menjadi dua bagian yaitu bagian kaki dan badan, sedangkan bagian kepala telah terlepas. Bagian kaki terdiri dari empat sisi dengan tinggi $13 \mathrm{~cm}$ dan lebar $15 \mathrm{~cm}$, serta memiliki hias panil berbentuk jendela khas batu nisan Aceh. Bagian badan juga terdiri dari empat sisi dengan tinggi $31 \mathrm{~cm}$ dan lebar $13-15 \mathrm{~cm}$, dengan kombinasi hias berupa kuncup lotus dan ukiran khas bunga Aceh. Namun tampaknya batu nisan bagian badan ini diletakkan dalam kondisi terbalik pada masa perbaikan.

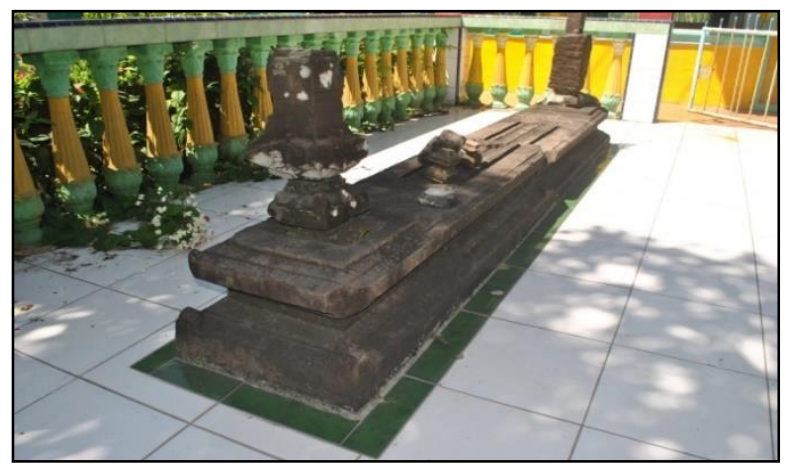

Gambar 2. Makam I pada Kompleks Makam Datuk Tongah

Batu nisan sebelah utara memiliki tinggi $67 \mathrm{~cm}$ yang dapat dibagi menjadi tiga bagian yakni bagian kaki, badan dan kepala. Bagian kaki terdiri dari empat sisi dengan tinggi $10 \mathrm{~cm}$ dan lebar $15 \mathrm{~cm}$ serta hiasan panil pintu berbentuk jendela Aceh. Bagian badan juga terdiri empat sisi dengan tinggi 39 cm dan lebar $13 \mathrm{~cm}$ dengan hias motif toreh berbentuk sisir tidak beraturan. Bagian kepala juga terdiri dari emat persegi dengan dua tingkatan dengan tinggi $15 \mathrm{~cm}$ dengan motif hias lotus.

Tampaknya bagian badan batu nisan sisi utara tidak asli dan merupakan penambahan pada masa perbaikan. Berdasarkan bentuk dan unsur hias Makam I ini menunjukkan bahwa makam mendapat pengaruh dari tradisi batu Aceh yang berkembang sejak abad ke14 M. Untuk itu penanggalan relatif makam I berasal dari abad ke-16 - ke-17 M dengan menggunakan tipologi batu Aceh tipe H (Suprayitno, 2011; Yatim, 1988). Tidak diketahui siapa tokoh dan tanggal pasti pemakaman sebab pada kedua batu nisan tidak memuat inskripsi. 


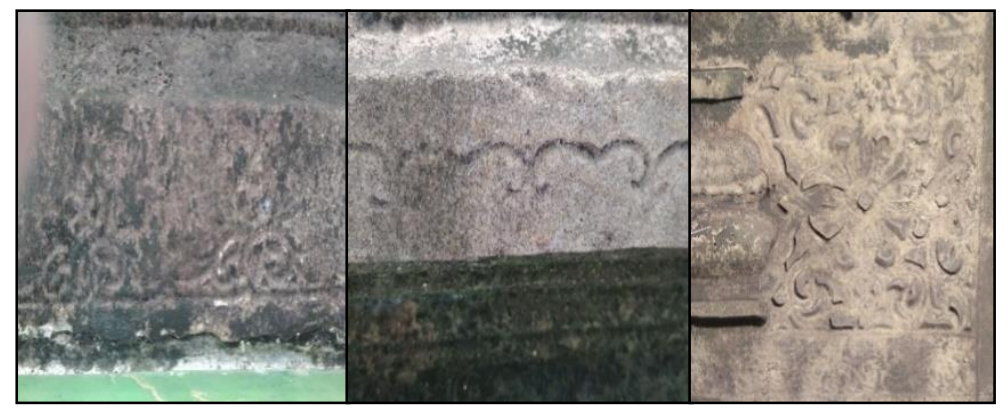

Gambar 3. Ornamen hias pada Makam I

Makam ini memiliki panjang 2, $9 \mathrm{~m}$ dan lebar $54 \mathrm{~cm}$ dengan pembagian bentuk terdiri dari jirat dan batu nisan. Tinggi jirat $27 \mathrm{~cm}$ dan lebar $54 \mathrm{~cm}$ dengan hiasan berupa anyaman tali yang menyerupai tanaman merambat. Dari bentuknya serupa dengan dua jenis tanaman khas Aceh yang sering diaplikasikan dalam unsur hias batu Aceh yakni bunga poeta taloe lhee dan bunga ajoe-ajoe (Yatim, 1988). Pada bagian permukaan jirat memiliki hiasan bunga awan dengan teknik stilir perpaduan antara elemen pola anyam tali dan ujung-ujung berbentuk tumbuhan, serta ditambah dengan hiasan anyam geometri pada bagian pinggirnya. Batu nisan sebelah utara memiliki tinggi 76 $\mathrm{cm}$ dengan diameter $51 \mathrm{~cm}$. Batu nisan ini berbentuk silindris tanpa hiasan sedikit pun. Sekilas bentuknya mirip dengan batu nisan khas Barus yang juga berbentuk silindris namun memiliki perbedaan pada bagian kepala.

Pada kepala batu nisan khas Barus terdapat hiasan berbentuk lotus, sedangkan pada batu nisan Makam Datuk Tongah tidak ada. Pada bagian kaki nisan terdapat semacam alas berbentuk oksagonal. Begitu pula halnya dengan batu nisan sebelah selatan juga memiliki identifikasi serupa dengan batu nisan sebelah utara. Agak sulit menentukan tipologi batu nisan ini sebab belum pernah ditemukan sebelumnya termasuk untuk kawasan Aceh yang memiliki deposit batu nisan kuno yang sangat melimpah. Namun berdasarkan unsur hias yang ada setidaknya menunjukkan usia relatif makam berasal dari abad ke-16 sampai ke-17 M dan mendapat pengaruh dari tradisi batu nisan Aceh. Batu nisan ini memiliki persamaan dengan nisan-nisan pada kompleks makam di Kota Aceh Besar yang dikenal dengan kompleks makam Syiah Kuala. Bentuk nisan, jirat serta pola hias yang digunakan. Tengku Syah Kuala memiliki nama Syekh Abdurrauf as-Singkili. Menilik namanya, Tengku Syah Kuala berasal dari daerah Singkil, salah satu kabupaten di Provinsi Aceh. Kabupaten Singkil berbatasan langsung dengan Kabupaten Tapanuli tengah yang di dalamnya terdapat kecamatan Barus yang sempat memiliki nama besar pada masanya. 
Nama Barus juga dikaitkan sebagai pusat penyebaran Islam di nusantara. Barus diperkirakan juga sebagai wilayah yang menghasilkan cukup banyak ulama, kemudian menyebarkan Islam ke nusantara di bawah bendera kerajaan-kerajaan di Aceh. Syekh Abudurrauf as-Singkili atau lebih dikenal sebagai Tengku Syah Kuala merupakan seorang ulama besar yang mengembangkan Tarekat Syatarriyah. Syekh Abdurrauf as-Singkili lahir di Singkil pada tahun $1024 \mathrm{H} / 1615 \mathrm{M}$ dan meninggal pada tahun 1105 H/1693 M. Terdapat persamaan-persamaan antara nisan Syah Kuala dengan Makam Datuk Tengah, baik dari bentuk maupun pola hias. Hal ini menunjukkan bahwa keduanya berasal dari satu pabrik pembuatan yang sama dengan periodisasi yang tidak terlalu berbeda jauh.

Sejarah mengenai asal muasal makam Datuk Payung sejauh ini hanya bisa ditelusuri melalui metode sejarah lisan. Sampai sekarang belum ditemukan satu pun bukti tertulis yang berisi informasi terkait. Cerita mengenai sosok Datuk Payung dan keberadaan makamnya pun kemungkinan besar memang belum pernah ada yang menuliskannya. Walaupun terbilang mengecewakan, namun kondisi seperti ini memang sangat lumrah terjadi. Umumnya masyarakat tradisional di Indonesia lebih akrab dengan tradisi lisan ketimbang tulisan. Terlebih lagi orang Melayu diwarisi dengan tradisi lisan yang cukup dominan. Walaupun ada banyak sekali hikayat-hikayat populer yang berhasil ditulis ulang, namun tidak demikian halnya dengan kisah-kisah dengan lingkup lebih kecil. Kisah-kisah lokal yang diceritakan turun-temurun biasanya sudah cukup dipercayai apa adanya oleh masyarakat setempat. Kondisi seperti ini memperbesar peluang munculnya banyak versi sekaligus memperkecil upaya kritik masyarakat tentang beragam versi kisah yang mereka dengar. Ini merupakan kendala utama bagi peneliti yang melakukan penelusuran sejarah lokal di kawasan Pantai Timur Sumatera bagian utara.

Dalam konteks penelusuran informasi terkait makam Datuk Payung melalui tradisi lisan, tim peneliti telah melakukan penjajakan dan seleksi terhadap tokoh-tokoh masyarakat setempat. Beberapa orang yang teridentifikasi memiliki wawasan dan informasi yang cukup kredibel dan meyakinkan dipilih sebagai informan utama. Mereka adalah bapak Yusuf dan bapak Syahroni.

Beberapa tokoh masyarakat dari kalangan Tionghoa yang ditemui merupakan anggota dari anggota Yayasan Tionghoa Gysan, yaitu nama yayasan yang memfasilitasi urusan kematian dan pemakaman, seperti Bapak A Liem, A Yong, dan A Feng. Bapak A Liem adalah salah satu pengurus yayasan 
dan orang yang sangat dekat dengan ketua Yayasan Tionghoa Gysan. Berkat bantuan A Lim, program Pengabdian kepada Masyarakat ini mendapat dana bantuan pelestarian makam Datuk Payung. Ketua Yayasan Tionghoa Gysan antusias mendengar rencana pelestarian makam tersebut dan lantas menebus separuh dari total biaya belanja material untuk pembangunan pagar beton. A Liem jarang berada di kampung Paya Bakung. Karena urusan pekerjaannya dia lebih sering berada di Medan. Bapak A Yong adalah salah satu anak dari keluarga Tionghoa pertama yang menjadi penduduk di kampung Paya Bakung. Ayahnya bernama Ho Sun yang merupakan pengurus pertama Yayasan Tionghoa Gysan.

Menurut penuturan Yusuf, Ho Sun sebagai orang Tionghoa pertama yang datang ke kampung Paya Bakung. Dia membeli buah kelapa dari kebun keluarga Pak Yusuf dan memulai usaha pembuatan minyak kelapa. Pabrik minyak kelapa yang dirintisnya kemudian hari menjadi usaha keluarga. Kini pabrik tersebut sudah tiada karena sudah lama berhenti akibat berkurangnya produktivitas buah kelapa. Bapak A Yong kini dikenal sebagai penanggungjawab urusan adat menjelang Ceng Beng. Bapak A Feng adalah orang yang dikenal sebagai kontraktor pemakaman. Dia adalah orang yang menerima pesanan dan membangun makam sesuai permintaan keluaga duka. Dia mempekerjakan sejumlah tukang bangunan dari warga sekitar untuk membantu mengolah material menjadi bangunan kuburan khas Tionghoa.

Menurut cerita yang diingat Bapak Yusuf, satu rombongan musafir ditemukan tewas mengapung di sungai. Tidak ada yang tahu kemalangan apa yang menimpa rombongan tersebut ketika berlayar menyusuri sungai yang sekarang dikenal sebagai Sungai Mati. Kejadian itu tidak diketahui secara pasti kapan dan tahun berapa. Menurut bapak Yusuf cerita itu sudah ada sejak sekitar 200 tahun silam.

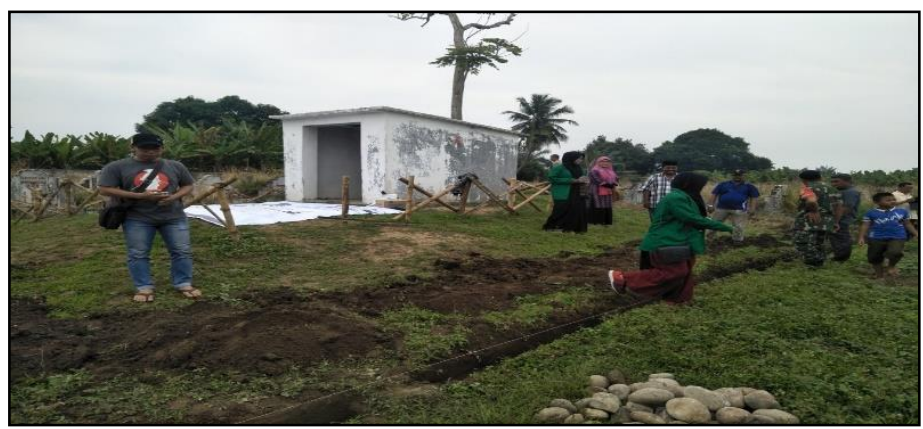

Gambar 4. Kompleks Makam Datuk Payung dalam Proses Pemugaran oleh Mahasiswa Prodi Sejarah Peradaban Islam UINSU 
Tim memperkirakannya terjadi sekitar awal abad ke-19. Tidak diketahui asalnya dari mana dan menuju ke mana rombongan itu. Diketahui ada delapanbelas jenazah yang menjadi korban jiwa dan hanya satu jenazah yang dikenali bernama Datuk Payung. Kemungkinan besar dialah pemimpin kelompok yang nahas tersebut. Nama dan identitas Datuk Payung pun masih simpang siur. Tokoh-tokoh masyarakat sekitar yang memperkirakan dia adalah seorang Melayu muslim karena istilah datuk dan payung sangat akrab di dalam budaya orang Melayu. Ada pula yang memperkirakan dia adalah seorang Tionghoa, namun tidak ada bukti dan alasan logis yang menguatkan.

Berdasarkan laporan dari narasumber bahwa kedelapanbelas jenazah tersebut dimakamkan di sebuah bukit yang sekarang dikenal sebagai "Makam Keramat Datuk Payung" atau "Keramat Delapanbelas". Pada zaman itu, biasanya orang yang meninggal akan dimakamkan tidak jauh dari lokasi terakhir dia berada. Memulangkan jenazah ke tempat asalnya adalah suatu urusan yang berat, terlebih ajaran Islam mengharuskan jenazah harus dimakamkan segera mungkin, apalagi jenazah musafir yang tidak diketahui tempat asalnya. Karena jumlah jenazah yang banyak dan waktu yang mendesak, maka pemakaman dilakukan secara massal, tanpa gundukan jirat, tanpa batu nisan tertulis, serta jaraknya cukup rapat ketimbang makam kebanyakan.

Bapak Yusuf menyakini bahwa makam Datuk Payung adalah kuburan massal. Kedelapanbelas jenazah tersebut dikuburkan dalam satu lubang besar. Adapun kedelapanbelas batu kali yang dijadikan sebagai nisan tersebut dipancang semata-mata agar masyarakat sesudahnya mengenali bahwa tempat itu merupakan makam milik delapanbelas orang dari rombongan Datuk Payung. Menurut Tim Peneliti cerita tersebut memang tidak dapat dipercaya sepenuhnya karena tidak ada bukti yang menguatkan, namun dirasa cukup masuk akal terlepas dari adanya bagian-bagian dari cerita tersebut yang mungkin saja telah berubah selama lima generasi keluarga bapak Yusuf.

Makam Datuk Payung berada di Jalan Kuburan Cina, Kelurahan Martubung dengan titik koordinat $3^{\circ} 42^{\prime}, 44,90^{\prime \prime}$ Lintang Utara dan $98^{\circ} 41^{\prime}$, 12,39" Lintang Timur. Kompleks makam ini berada di tengah-tengah kompleks pekuburan warga Tionghoa. Kawasan pekuburan warga Tionghoa dikelola oleh Yayasan Tionghoa Gysan. Secara keseluruhan kontur tanah di lahan tersebut relatif datar, hanya ada satu bukit kecil dengan luas sekitar 10 m2 dan tinggi sekitar $70 \mathrm{~cm}$. Makam Datuk Payung tepat di atas bukit tersebut. Makam tersebut terkesan seperti pemandangan yang kontras di antara 
hamparan ribuan nisan berukuran besar milik warga Tionghoa yang berjajar rapi dan simetris. Ketika tim peneliti melakukan survei, kondisi makam dan nisan sangat memprihatinkan. Bukit kecil tersebut ditumbuhi semak-semak rumbut liar berduri sehingga menyelimuti yang nisan-nisan ada di situ. Hanya ada satu batang pohon sengon yang berdaun jarang berdiri agak miring di salah satu sudut bukit serta satu batang pohon mahoni muda yang telah kering dan mati.

Pada siang hari yang terik, tempat itu terasa sangat gersang dan panas. Batu nisan yang masih tampak utuh dan berada di posisi aslinya hanya lima buah saja, sedangkan yang lainnya telah tercabut dan bergeser secara acak dan terkumpul di dalam bilik doa. Delapanbelas batu nisan keramat dan bilik doa selama ini digunakan sebagai media untuk ritual warga Tionghoa.

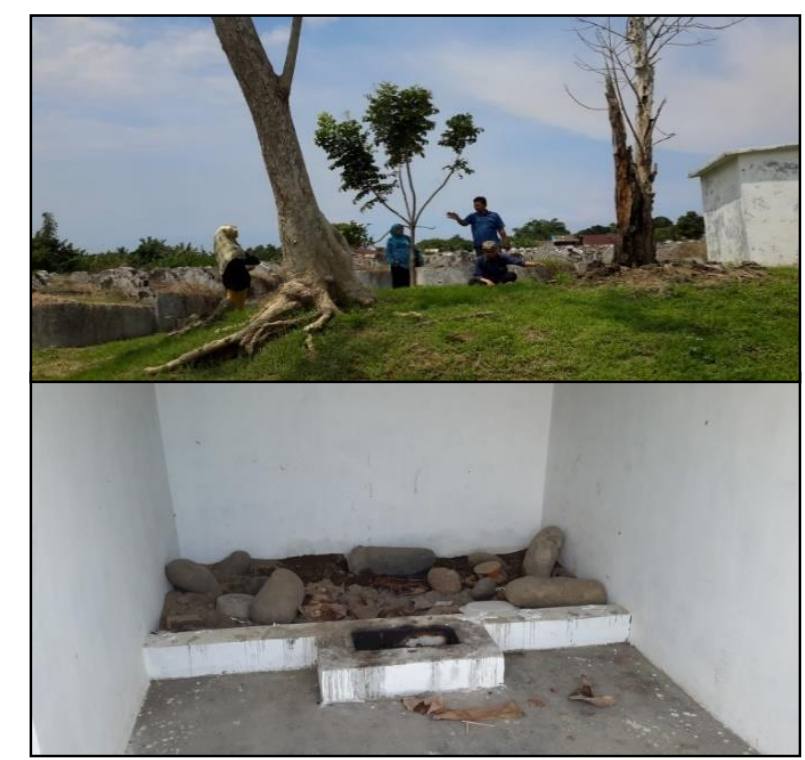

Gambar 5. Kondisi Makam Datuk Payung Sebelum Dipugar

Nisan di makam Datuk Payung berjumlah delapanbelas buah. Semua nisan merupakan batu kali berbentuk lonjong. Batu-batu tersebut berbentuk alami tanpa dipahat dan tanpa inskripsi, sehingga tipologinya tidak jelas untuk dijadikan patokan penanggalan relatif. Menurut pengamatan tim peneliti dan diperkuat oleh ingatan tokoh masyarakat sekitar, memang posisi kedelapanbelas nisan tersebut sejak dulu sejajar dengan jarak yang rapat. Hal itu masih tampak dari posisi kelima nisan yang masih tertanam kuat. Belakangan diketahui bahwa kondisi demikian memiliki alasan historis. 
Meski tidak ada satu pun batu nisan yang memiliki inskripsi dan tipologi yang jelas untuk menjadi patokan penanggalan relatif, namun kompleks makam yang berada di atas tanah tinggi yang sengaja ditimbun dengan penggunaan teknik talut sebagai penguatnya mengingatkan pada bentukbentuk kompleks makam yang ada di Barus. Dalam kepercayaan lokal masyarakat Barus, bukit-bukit buatan seperti itu disebut munggu yang fungsinya sebagai lokasi untuk melakukan I'tikaf (Perret \& Surachman, 2015). Bentuk kompleks makam seperti itu juga mengarah pada gaya pemakaman yang sering diterapkan dalam ajaran tasawuf.

Di antara kedelapanbelas nisan tersebut, tidak diketahui secara pasti yang mana nisan milik orang yang dikenal sebagai Datuk Payung tersebut, namun ada satu batu nisan yang rupanya sedikit berbeda di antara yang lainnya. Konon nisan tersebut tidak bisa dicabut dan kondisinya tidak utuh atau bagian atas batu sudah pecah. Warga sekitar mempercayai batu nisan itu adalah milik Datuk Payung yang dianggap keramat. Warga lazim menyebut kompleks makam tersebut sebagai "makam keramat". Warga Tionghoa yang memiliki kedekatan secara spiritual dengan makam keramat Datuk Payung menyebutnya sebagai "Keramat Delapanbelas".

Terdapat satu bangunan dari beton berukuran 1,5 × 1,5 meter yang dibangun oleh warga Tionghoa sejak dua tahun belakangan. Bangunan tersebut digunakan sebagai tempat melakukan ritual, namun bukanlah sebuah tempat ibadah seperti Pekong. Di dalamnya terdapat tempat khusus untuk menancapkan dupa dan membakar kemenyan. Bisa dikatakan ritual yang dilakukan di tempat itu tidak mewakili ajaran agama Buddha dan Konghucu. Tidak ada orang Islam yang berdoa dan bersemedi di tempat itu. Dalam ajaran Islam praktik demikian tergolong perbuatan syirik dan dosa besar. Warga Melayu dan muslim setempat memang taat dalam hal itu. Hanya sejumlah kecil orang Tionghoa saja yang memiliki hajat khusus. Oleh karena itu untuk memudahkan penyebutan, tim menamai bangunan tersebut sebagai "bilik doa".

Jauh sebelum bilik doa dibangun, makam keramat Datuk Payung kerap disinggahi oleh warga Tionghoa untuk melakukan ritual. Seiring waktu berlalu, makam tersebut semakin dianggap sakral dan dapat membawa berkah bagi warga Tionghoa yang melakukan ritual di sana. Kemudian hari warga Tionghoa mulai melakukan "Sembahyang Keramat" setahun sekali untuk menghormati makam keramat tersebut. Warga Tionghoa yang meyakini dan memiliki pengalaman spiritual dengan makam tersebut ikut berpartisipasi 
mempersiapkan dan melaksanakan Sembahyang Keramat bersama-sama secara gotong-royong. Sembahyang Keramat rutin dilaksanakan pada tanggal 9 September setiap tahunnya. Biasanya dilakukan upacara sederhana sesuai kepercayaan untuk menghormati arwah leluhur dan dilaksanakan pemotongan hewan kurban sebagai persembahan.

Pada tahap pemotongan kurban warga Tionghoa melibatkan warga muslim untuk berpartisipasi. Penyembelihan hewan (biasanya kambing) dilakukan sesuai ajaran Islam. Daging kurban dimasak dan dinikmati bersamasama, sehingga tidak ada sekat agama dalam situasi itu. Warga Melayu dan muslim walaupun pada awalnya keberatan dengan praktik ritual tersebut, namun pada akhirnya mereka lebih toleran dan membiarkannya selama tidak ikut bersembahyang dan hanya ikut menyembelih kurban. Hubungan demikian mencerminkan adanya harmonisasi antara dua penganut agama yang berbeda yang hidup berdampingan. Tradisi ini sudah berlangsung sejak dekade 1970an. Sejak awal tradisi tersebut muncul hingga sekarang, belum pernah terjadi gesekan sosial yang melahirkan konflik akibat praktik ritual warga Tionghoa di atas makam keramat Datuk Payung yang masih diperdebatkan apakah makam milik delapanbelas orang Melayu muslim ataukah orang Tionghoa muslim.

Di antara lima kompleks makam kuno yang berhasil diidentifikasi dan diinventarisasi di Kelurahan Martubung yaitu: Makam Datuk Hasan, Makam Datuk Payung, Makam Datuk Tongah, Makam Datuk Dadih dan Makam Datuk Hitam, maka sebagai tindak lanjut dari program penelitian ini hanya dua kompleks makam saja yang dipilih sebagai lokasi pengabdian kepada masyarakat oleh mahasiswa SPI UINSU untuk tahun 2019, yaitu; Makam Datuk Payung dan Makam Datuk Tongah. Keduanya dipilih atas dasar beberapa pertimbangan, yaitu: efektivitas pelaksanaan program, efisiensi waktu dan dana, serta agar tim lebih fokus bekerja selama lima bulan. Khusus Kompleks Makam Datuk Payung, kondisinya yang sangat memperihatinkan dan sangat prioritas untuk segera diambil tindakan penyelamatan dan pelestarian.

Upaya pelestarian Makam Datuk Payung dan Datuk Tongah pada penelitian ini dilakukan sebagai bentuk pengabdian kepada masyarakat. Pihak yang dilibatkan dalam program ini adalah Program Studi Sejarah Peradaban Islam UINSU, Kelurahan Martubung dan masyarakat setempat. Khusus Makam Datuk Payung tim melibatkan Yayasan Tionghoa Gysan sebagai pemilik lahan. 
Adapun program pengabdian yang dilakukan di Kompleks Makam Datuk Payung dapat dibagi menjadi beberapa tahap: Pertama, penjajakan dan musyawarah dengan pihak-pihak terkait. Pihak Kelurahan Martubung memfasilitasi dengan mengubungkan tim kepada berbagai pihak. Semua pihak bertemu dan melakukan musyawarah di kantor Kelurahan Martubung dan dilanjutkan dengan meninjau langsung lokasi yang dimaksud. Program ini mendapat dukungan dan fasilitas dari semua pihak. Secara perizinan dan administrasi, tim mendapat banyak kemudahan. Selain itu pihak Kelurahan Martubung juga memberi sejumlah data terkait. Pada tahap ini semua pihak sepakat bahwa perlunya langkah-langkah penyelamatan terhadap kompleks Makam Datuk Payung, yaitu: pembangunan sebidang pagar beton, penimbunan permukaan tanah yang lubuk, pembongkaran bilik doa, penanaman bunga dan pohon. Rencana ini sepakat dilaksanakan secara gotong royong.

Kedua, sosialisasi kepada masyarakat. Sosialisasi dilakukan di Kantor Kelurahan Martubung dengan mengundang beberapa orang masyarakat dan beberapa orang tokoh masyarakat. Adapun masyarakat yang ikut berpartisipasi adalah yang memiliki waktu luang dan memiliki keahlian dalam pekerjaan bangunan. Sementara itu tokoh masyarakat yang ikut berpartisipasi juga yang memiliki waktu luang dan memiliki kemudahan memberi sumbangan dalam berbagai bentuk secara sukarela, seperti peralatan kerja, bibit bunga dan pohon, maupun tenaga.

Ketiga, pembangunan pagar beton. Proses pembangunan pagar beton dilakukan selama 6 hari. Setelah material sudah disediakan, maka beberapa orang masyarakat mulai menggali tanah untuk pondasi pagar pada hari pertama. Pada hari itu juga dilaksanakan acara seremonial peletakan batu pertama yang dihadiri oleh pihak-pihak terkait. Pekerjaan dilanjutkan dengan pengecoran semen. Pada hari kedua pengecoran rampung dilakukan dan dilanjutkan dengan memasang batu bata yang rampung pada hari ketiga. Pada hari keempat ketinggian pagar telah mencapai ukuran yang direncanakan, yaitu $70 \mathrm{~cm}$. Hal ini dikarenakan penyesuaian dana dan waktu. Namun tidak mengurangi substansi tujuan pagar itu dibangun.

Pekerjaan dilanjutkan dengan proses plaster halus sehingga permukaan bata ditutupi oleh semen. Proses ini rampung pada hari kelima. Pada hari kelima dan keenam, dilakukan pembongkaran bilik doa sehingga permukaan tanah di kompleks tersebut lebih bersih dan bebas dari benda apapun. Selain pembangunan pagar beton, permukaan tanah yang lubuk juga ditimbun, 
sehingga kontur tanah di sekitar nisan lebih rata. Pekerjaan pada tahap ini diawasi dan difasilitasi oleh pimpinan proyek yang ditunjuk bersama, yaitu bapak A Feng.

Keempat, pemugaran/penataan ulang nisan. Tim yang bekerja pada tahap ini adalah mahasiswa dan tokoh masyarakat yang difasilitasi oleh bapak Yusuf. Mahasiswa mendapat banyak sekali bantuan dengan peran bapak Yusuf yang ingatannya sangat diandalkan ketika penataan ulang nisan pada titik aslinya. Nisan yang berhasil ditata ulang dari titik aslinya sebanyak 13 buah dari 5 nisan yang masih bertahan. Semua nisan dicat dengan warna putih dan diberi nomor agar mudah diidentifikasi pengunjung. Selain itu, bapak Yusuf, beberapa orang warga, dan mahasiswa ikut meratakan permukaan tanah yang telah ditimbun serta menanaminya dengan bunga yang menjalar, sehingga rumpun bunga tersebut kelak akan menghalangi tumbunya rumput ilalang.

Kelima, pemasangan plank tanda. Akhirnya tahap terakhir yang dilakukan adalah pemasangan plank sebagai tanda dan identitas kompleks Makam Kuno Datuk Payung sekaligus peresmian yang dihadiri oleh semua pihak terkait. Dengan demikian diharapkan warga saling menjaga keberadaan Makam Datuk Payung dan ikut melestarikannya.

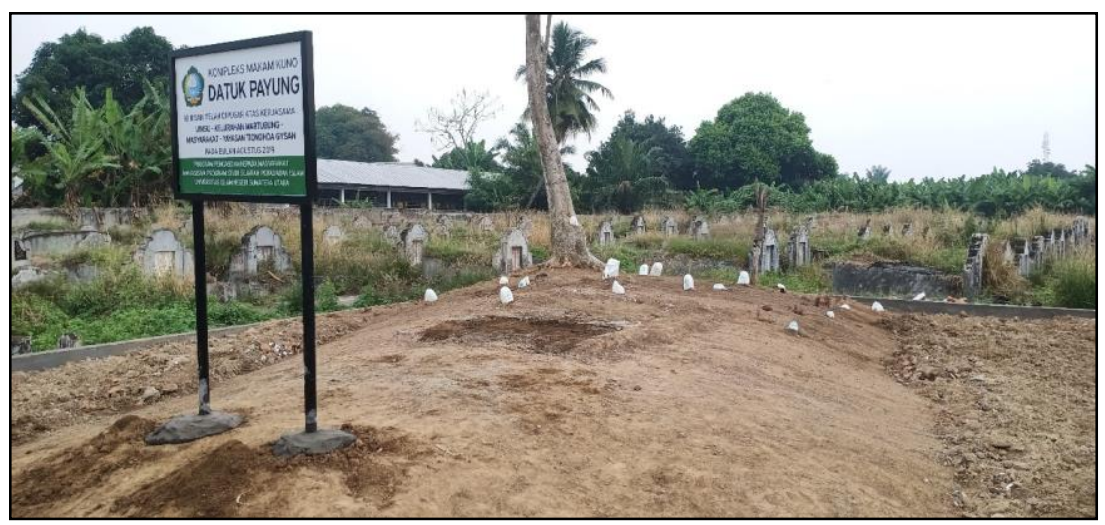

Gambar 6. Kompleks Makam Datuk Payung Setelah Dipugar

Adapun program pengabdian yang dilakukan di Kompleks Makam Datuk Tongah dilaksanakan secara lebih sederhana dengan tahapan yang lebih sederhana pula. Hal ini disebabkan memang kondisi makam yang sudah baik, sehingga hanya perlu dilakukan pembersihan dan perawatan secara singkat. Mahasiswa bersama tokoh masyarakat yang diwakili oleh bapak Syahroni melakukan pembersihan seperti mencabut rumput, menyapu, dan memberi plank tanda. 
Pengelolaan Makam Datuk Payung dan Datuk Tongah sangat mengandalkan inisiatif dan partisipasi masyarakat di sekitarnya. Sejauh ini masih sedikit warga yang secara sukarela memiliki kepedulian untuk mengelola makam kuno di sekitar mereka. Di antaranya adalah sosok bapak Yusuf dan Syahroni yang perannya paling menonjol. Setelah program ini selesai dilaksanakan, diharapkan masyarakat turut aktif melindungi, mengelola, dan melestarikan makam-makam di sekitar mereka sesuai dengan inisatif dan kemampuan masing-masing. Tokoh masyarakat diharapkan dapat mendampingi warga yang memiliki kepedulian sekaligus menumbuhkan kesadaran bagi warga yang lain. Stakeholder diharapkan memberikan dukungan moril maupun materil serta memberi pendampingan kepada masyarakat secara berkesinambungan. Akademisi diharapkan memperbanyak program penelitian dan pengabdian kepada masyarakat agar makam-makam yang belum mendapat perhatian, segera mendapatkan perlakuan pelindungan dan pelestarian.

Sejauh ini, masih terbilang sedikit masyarakat yang aktif mengelola Makam Datuk Payung dan Datuk Tongah. Pada Makam Datuk Payung, sosok bapak Yusuf tampil sangat dominan mulai dari awal program ini disosialisasikan hingga program selesai dilaksankan. Bapak Yusuf telah banyak berkontribusi dalam pelestarian Makam Datuk Payung, tempat yang memiliki kedekatan dan kenangan dalam ingatannya. Bapak Yusuf kerap memperhatikan kompleks makam dan merawat bunga yang telah ditanam. Di mata tim peneliti, sosok bapak Yusuf layak diamanahkan sebagai juru kunci Makam Datuk Payung dan menjadi inspirasi bagi warga lainnya.

Makam Datuk Tongah masih mengandalkan sosok bapak Syahroni sebagai juru kunci dan tokoh masyarakat yang paling aktif berkontribusi bagi keberadaan kompleks makam dan Masjid Al-Mukarromah. Dari hasil diskusi antara tim peneliti dengan bapak Syahroni, di masa depan melalui programprogram lainnya perlu dibangun museum dan pusat informasi di sekitar Makam Datuk Tongah atau masih di kompleks Masjid Al-Mukarromah. Hal ini merupakan rencana jangka panjang agar masyarakat mendapat kemudahan akses informasi terkait makam-makam kuno di sekitar Kelurahan Martubung dari museum dan pusat informasi tersebut. Tidak hanya itu, rencana tersebut akan membuka lapangan kerja dan peluang ekonomis lainnya bagi masyarakat, salah satunya melalui potensi-potensi wisata rohani yang sangat terbuka lebar apabila dikembangkan secara serius. 
Upaya yang dilakukan dalam pelestarian terhadap peninggalan arkeologi dan budaya di makam kuno tersebut adalah dengan cara mengamankan dan menyelamatkan warisan budaya yang terancam hilang atau rusak yaitu dengan melakukan perlindungan fisik, pemindahan, ekskavasi dan perekaman. Bukan hanya perlindungan dengan adanya pemindahan saja, tetapi harus adanya pemeliharaan dengan cara melindungi dan merawat warisan budaya supaya tetap terjaga dan dapat dinikmati oleh generasi penerus. Selain itu, upaya pemugaran juga penting dalam upaya untuk melestarikan peninggalan budaya tersebut, yaitu dengan adanya pemugaran (restorasi) ataupun upaya untuk mengembalikan keadaan makam kuno tersebut agar mendekati bentuk semula.

\section{Temuan Makam Kuno Islam dan Perkembangan Islam di Kota Medan}

Berdasarkan hasil temuan dari makam kuno yang ada di Kota Medan merupakan bukti bahwa eksistensi suatu kebudayaan yang cukup tua dan sebagai salah satu pintu masuk dan berkembangnya Islam dikawasan pesisir Timur Sumatera Utara. Nisan pertama yang terdapat pada kompleks makam Datuk Tongah memiliki persamaan dengan nisan-nisan pada kompleks makam di Kota Aceh Besar yang dikenal dengan kompleks makam Syiah Kuala. Bentuk nisan, jirat dan pola hias yang digunakan sama dengan yang digunakan oleh makam Tengku Syiah Kuala/ lebih dikenal dengan nama Syekh Abdurrauf as Singkili. Persamaan antara nisan Syiah Kuala dengan makam Datuk Tongah menunjukkan bahwa keduanya berasal dari satu pembuat nisan tersebut. Maka dari itu dapat penanggalan makam ini berasal dari abad ke-17 M. Sedangkan pada nisan kedua pada kompleks makam Datuk Tongah merupakan nisan dengan tipe Aceh pada masa Aceh Darussalam yang diperkirakan berasal dari tahun 1600 M. Nisan tersebut merupakan nisan dengan tipe H dari abad ke-16$17 \mathrm{M}$. Kondisi kedua nisan tersebut dirombak sedemikian rupa oleh masyarakat sekitar sehingga bentuknya sudah berbeda dengan dengan bentuk aslinya.

Komplek makam lainnya yang mengalami proses pemahatan yaitu nisan dan makam Datuk Dadi. Nisan makam Datuk Dadi hanya tertinggal sepotong dan diperkirakan merupakan potongan bagian atas. Berbeda dengan makam Datuk Tongah yang bagian atasnya berbentuk bulat pada bagian atasnya rata. Selain itu, nilai penting makam kuno yang ada di Kota Medan menunjukkan bahwa kawasan makam yang ada di Desa Martubung sangat berpotensi bagi ilmu pengetahuan seperti sejarah, antropologi, arkeologi dan bidang ilmu lainnya. situs yang pernah eksis pada abad ke-16 $M$ tersebut 
menyimpan berbagai potensi dalam pengembangan ilmu pengetahuan. Jika dikaitkan dengan aspek substansif, makam kuno ini memberikan informasi untuk memaparkan atau menjelaskan peristiwa sejarah masuk dan berkembangnya Islam di Sumatera Utara yang bukti-buktinya masih dapat dilihat hingga saat ini. makam kuno Martubung juga memberikan informasi yang menjelaskan perubahan budaya dalam bentang waktu yang lama melalui proses adaptasi manusia terhadap lingkungan. Pengembangan ilmu pengetahuan juga memiliki kaitannya dengan asek arsitektur dan teknologi yang pernah digunakan dalam aktivitas keseharian makam kuno Martubung.

\section{Simpulan}

Makam-makam kuno yang ada di Kota Medan merupakan bukti bahwa eksistensi suatu kebudayaan sebagai salah satu pintu masuk dan berkembangnya Islam dikawasan pesisir Timur Sumatera Utara. Adapun makam kuno bercorak Islam yang teridentifikasi adalah Makam Datuk Hasan, Makam Datuk Payung, Makam Datuk Tongah, Datuk Dadih dan Makam Datuk Hitam. Nilai penting makam kuno yang ada di Kota Medan menunjukkan bahwa kawasan makam sangat berpotensi bagi ilmu pengetahuan seperti sejarah, antropologi, arkeologi dan bidang ilmu lainnya serta menyimpan berbagai potensi dalam pengembangan ilmu pengetahuan. Upaya yang dilakukan oleh pemerintah setempat dalam pelestarian terhadap peninggalan arkeologi dan budaya di makam kuno tersebut adalah dengan cara mengamankan dan menyelamatkan warisan budaya yang terancam hilang atau rusak yaitu dengan melakukan perlindungan fisik, pemindahan, ekskavasi dan perekaman, pemeliharaan (melindungi dan merawat) warisan budaya supaya tetap terjaga dan dapat dinikmati oleh generasi berikutnya serta upaya pemugaran untuk mengembalikan keadaan makam kuno tersebut agar mendekati bentuk semula, dan tentunya menjauhkan dari ancaman nyata bagi eksistensi tempat-tempat bersejarah di sekitarnya.

\section{Referensi}

Afandi, A., Sucipto, M. H., \& Muhid, A. (2016). Modul Participatory Action Research (PAR) untuk Pengorganisasian Masyarakat (Community Organizing). Lembaga Penelitian dan Pengabdian kepada Masyarakat, UIN Sunan Ampel Surabaya.

Agrawal, O. P., \& Barkeshli, M. (1997). Conservation of Books, Manuscripts, and Paper Documents. INTACH. 
Ambary, H. M., \& Ali, B. (1988). Aceh dalam Retrospeksi dan Refleksi Budaya Nusantara. INTIM.

Azhari, I. (2011). Asal Usul Kota Medan Menurut Riwayat Hamparan Perak. Perpustakaan Daerah Sumatera Utara.

Bintarto, H. R. (1995). Keterkaitan Manusia, Ruang dan Kebudayaan. Berkala Arkeologi: Manusia dalam Ruang, Studi Kawasan dalam Arkeologi Tahun XV.

Chambers, R. (1996). PRA (Participatory Rural Appraisal): Memahami Desa Secara Partisipatif. Kanisius.

Duli, A., Rahman, A., Sulistyo, B., Muhaeminah, Mutmainnah, Raodah, Rosmawati, \& Sumalyo, Y. (2013). Monumen Islam di Sulawesi Selatan (M. A. R. Effendy (Ed.)). BPCB Makassar bekerjasama dengan Identitas Unhas dan Danarosi Media.

Hartini, S. (2011a). Laporan Penelitian Situs Dunia di Sumatera Utara "Kota Rentang dan Pulai Kampai."

Hartini, S. (2011b). Perekaman Peninggalan Sejarah Budaya Islam di Sumatera Utara.

Joentono. (1996). Pengamanan dan Konservasi Arkeologi. Pertemuan Ilmiah Arkeologi VII Jilid 2.

Kasnowihardjo, G. H. (2001). Manajemen Sumber Daya Arkeologi. Lembaga Penerbitan Universitas Hasanuddin.

Kota Medan dalam Angka 2017. (2017). BPS Kota Medan.

Lombard, D. (2008). Kerajaan Aceh Zaman Sultan Iskandar Muda (1607-1636). KPG.

McKercher, B., \& Cros, H. du. (2002). Cultural Tourism: The Partnership Between Tourism and Cultural Heritage. Routledge.

Munjeri, D. (2007). Tangible and Intangible Heritage. In L. Smith (Ed.), Cultural Heritage: Critical Concepts in Media and Cultural Studies (Vol. 4). Routledge.

Oetomo, R. (2016). Metamorfose Nisan Aceh, dari Masa ke Masa. Berkala Arkeologi Sangkhakala, 19(2), 130-148.

Pariwisata, D. K. dan. (2008). Metode Penelitian Arkeologi. Departemen Kebudayaan dan Pariwisata.

Pearson, M., \& Sullivan, S. (2010). Looking after Heritage Places. The Basics of Heritage Planning for Managers, Landowners and Administrators. Melbourne University Press.

Perret, D. (2007). Some reflections on ancient Islamic tombstones known as Batu Aceh in the Malay world. Indonesia and the Malay World, 35(103), 313-340. https://doi.org/10.1080/13639810701677092

Perret, D., \& Surachman, H. (2015). Barus Negeri Kamper: Sejarah dari Abad ke-12 hingga Pertengahan Abad ke-17. KPG.

Prangnell, J., Ross, A., \& Coghill, B. (2010). Power relations and community involvement in landscape-based cultural heritage management practice: An Australian case study. International Journal of Heritage Studies, 16(1-2), 140-155. https://doi.org/10.1080/13527250903441838 
Sadirin, H. (1999). Prinsip-Prinsip Diagnostik dan Penanganan Konservasi Benda Cagar Budaya.

Salim, A. (2006). Teori \& Paradigma Penelitian Sosial. Tiara Wacana.

Sinar, T. L. (1971). Sari Sedjarah Serdang (Dengan Adat Istiadat Melaju dan Terombah Seri Padoka Godjah Pahlawan). Yayasan Luckman Sinar.

Sinar, T. L. (1991). Sejarah Medan Tempo Doeloe. Majlis Adat Budaya Melayu Indonesia.

Sinar, T. L. (2006). Bangun dan Runtuhnya Kerajaan Melayu di Sumatera Timur. Yayasan Kesultanan Serdang.

Sumanti, S. T., \& Batubara, T. (2019). Makam Kuno dan Sejarah Islam di Kota Medan (Studi Atas Potensi Wisata Sejarah). Atap Buku.

Suprayitno. (2001). Mencoba (Lagi) Menjadi Indonesia: Dari Federalisme ke Unitarisme (Studi tentang Negara Sumatera Timur 1947-1950). Tarawang Press.

Suprayitno, S. (2011). Evidence of the Beginning of Islam in Sumatera: Study on the Acehnese Tombstone Suprayitno. TAWARIKH, 2(2). https://doi.org/10.2121/TAWARIKH.V2I2.386

Suprayitno, S. (2012). ISLAMISASI DI SUMATERA UTARA: Studi Tentang Batu Nisan di Kota Rantang dan Barus. MIQOT: Jurnal Ilmu-ilmu Keislaman, 36(1). https://doi.org/10.30821/miqot.v36i1.113

Suryana. (2010). Metodologi Penelitian-Model Praktis Penelitian Kuantitatif dan Kualitatif. UPI Press.

Undang-Undang No. 11 Tahun 2010 tentang Benda Cagar Budaya, (2010).

Wibisono, S., Montana, S., \& Harkantiningsih, N. (1989). Berita Penelitian Arkeologi: Laporan Penelitian Situs-Situs Masa Islam di Sumatra Barat No. 39.

Yatim, O. M. (1988). Batu Aceh: Early Islamic Gravestones in Peninsular Malaysia. Museum Association of Malaysia. 